\title{
Phonology of Muna Language (Theoretical Review of Optimality)
}

\begin{tabular}{l} 
Article history: \\
\hline Received May $12^{\text {th }}, 2016$ \\
Revised June $10^{\text {th }}, 2016$ \\
Approved June $11^{\text {th }}, 2016$ \\
\hline Keywords: \\
Optimality; \\
Top; \\
Onset; \\
Complex; \\
Nocoda.
\end{tabular}

Author correspondence:

First Author, Faculty of Humanities

Halu Oleo University Kendari, Indonesia, 93232

Email: unhalu39@yahoo.co.id

\begin{abstract}
This article discusses the language Muna from the corner Phonological with optimality theory. Optimality theory is a continuation of the theory of generative transformation. Optimality theory using the model of linguistic analysis by utilizing the candidate as an input and output that has a relation between the two. The relationship between input and output is mediated in a formal mechanism in the form of plant and assessors. Generating create linguistic object and record the relationships of obedience in the input. Assessor in the hierarchy constraint is used to select the best candidates from the input as an optimal candidate produced by the plant. The analysis showed that the peak of the property syllables in the language Muna has one vowel, property onset syllable preceded single consonant, property complexes, only one consonant at the edge of the tribe, the property nocoda syllable ends with a vowel.
\end{abstract}

Copyright (c) 2016 International Journal of College and University. All rights reserved.

Article cited by | DOI |Orcid | OAI DOAJ | Thomson Reuters | Scopus |

\section{Introduction}

Muna Language (ML) is defined as one of cultural products in society because it is one of the seven cultural aspects. This language is located in Muna of SouthEast Sulawesi Province. The scope of this language embraces Muna Island, some parts of Buton Island that is under territory of Muna government, Buton regency, and Kendari. The development of function and Muna Language (ML) position shows feature of linguistic phenomenon, inherits with the reality of social and culture in society. Muna Language as a part of culture in society develops and can change together with the dynamics of social and culture in society. By this, to run its function and position, ML remains with its characteristics, and can develop dynamically to change. Study of Linguistic phenomenon related with the reality of social and culture in society is the focus of the study in Sociolinguistics. The study that is defined as the study of language variety is rarely conducted in ML. Attempts to conduct research in that direction was needed to study BM not only focused on the description of a language that is micro. In other words, there needs to be a balance between the micro and macro research studies. In particular, this study will discuss the theory of generative optimality which is a continuation of the study of the theory of generative transformative.

\footnotetext{
* Faculty of Humanties Universitas Halu Oleo Kendari, Indonesia
} 


\section{Research Method}

The methods and techniques that is used by the author in a scientific writing, purposively to make the study produced to be accurate and the accuracy depends on the methods and techniques that is used. In general, the methods and techniques that is used in a scientific writing can be divided into two types of methods e.g. qualitative and quantitative methods. In this case Moleong (1993: 15-20) see the difference the two types was based on differences of scientific paradigms and nature on the one hand and the characteristics of the methodology on the other hand. Hence, related with this study, the authors chose the qualitative method (Miles and Huberman, 1992: 1); Moleong, 1993: 3) as a foundation and approach in research, because this research is fundamentally depended on the observation of human speech in his/her own dialect territory as well as dealing with such persons in the language and the terminology.

\subsection{Concepts}

[a] Generator

Generation is a function that connects the input to the repsentation circuit, which may be the optimal output in the form of a special input. The generator is limited, it can only produce something that is composed of a universal vocabulary. in generator, a word can be removed, plus even rearranged unlimitly. unlimitly series of candidates created by generator comes from the inputs are not limited. Generator also served to indicate the correspondence between the input and output repsentation. This correspondence is very important in overcoming or evaluate compliance such as obedience $\mathrm{V}$ and obedience $\mathrm{K}$.

\section{[b] Constraints}

Constrains is a prerequisite or a set of constraints. Conditions or rules that contradict each other in order to obtain results contrary to the purpose to obtain optimal results. Constraints are part of the subordinate elements of a language. This means that each language uses the same constraint circuit. This assumption relates to the role of language in the universal aspects of human language. Constraints in each language commonly displayed in two possibilities, namely a positive way such as (COMPLEX) or by negative (COMPLEX). Placement constraints on the hierarchy of language is more than the property constrained itself. In another way, constraint violations that have a level of at least assumed to be optimum element while the high-level constraint is assumed as an element that is not optimal

[c] Assessment (Evaluator)

Assessment is a tool that serves to select the optimal candidate of a series of candidate made by generator. Optimal output selected by the assessor are the best candidates who meet the requirements or satisfying constraints with low-level offenses.

[d] Input (Input)

Input is a universal grammar that provides a vocabulary for representation of languages, all entries compiled from this vocabulary. The result, as a linguistic input are units form acceptable (well-formed)

[e] Output

Output is a produce sound which come from the input of derivation result in a complete shape. This forms line with the sound shape of language in phonetically.

[e] Candidate

Candidate is a linguistics forms which are going to be selected by an assessor as an output by creating an instigator as linguistics forms accepted. This forms are the derivation possibilities in a system.

\subsection{Theoretical Framework}

The theory that used in this paper is Optimality Theory (next, will be abbreviated with "OT") from two linguists, Prince and Smolensky (1991) which appeared for first time in phonological conference as a wide form of the concept of generative transformation. Smolensky's theory has been supported and completed by Archangeli and Langendoen (1997) in their concept of Optimality Theory an Overview. In this paper, the writer refers to the both of those explanation as principally is similar.

The basics of principal theory are as follows:

[a] Arranging the setting of constrained (such as requirements, condition or rule) which one to another contrast with aims to get optimal results.

[b] Determining a resistance at least contrast with the constrained.

[c] Believing a principal simplicity, but abundant for constrained interaction with constrained acceptor which reach out the others constrained.

[d] Analyzing of canonical form is based on the onset (the consonants placed in the beginning of syllable), summit (the vocals become a core of syllable) and coda (the consonants placed at the end of syllable)

Simplistically, it can be said that the concept of OT is organizing the formulation of rules that can unite a phenomenon, reality or facts and laws in logically and rationally for language data in universal. These principals are based on a basic concept which tells us that the objectives of the study in linguistic are as follows: [a] To determine and look for the characteristics of language in a universal property. 
[b] To believe that the providing property is belong to every single language.

[c] To think that the unique of universality on the language is not to similar with the other languages.

[d] Absolutely, the universality appears on the language.

[e] To know the distance of differences of variances in a language.

(Archangeli and Langendoen, 1887:2)

In phonetic rules, this theory pointed that (1) there are a sum of consonants which can be permitted in an onset, summit and coda, (2) there is a process of phonology such as dismissal, increment, assimilation, and so on. The processing of phonology is not only happened for the pattern of syllabic but also related to the aspects of the unique of that language sound system itself which are not always accepted on the other language. Syllable Typical properties form of the peak, is the syllable began with a consonant, onset is the syllable that having one vowel, not koda is the syllable-word ends with a vowel. * Complex is a syllable where should only be one consonant at the edge of the syllable, and the onset and the peak (syllables composed of consonants and vowels).

These five properties above, is not an absolute rule but only a general tendency. Therefore, there are language syllables as opposed to some property above. Syllable is a minimal constituent formed of a consonant followed by a vowel; When a syllable begins with a consonant, so the consonant eligible the onset, and if the syllable has one vowel, then the vowel it qualifies the peak. Optimality theory using model of linguistic analysis by utilizing the candidate as an input and output that has a relation between both of. The relationship between input and output is mediated in a formal mechanism in the form of generator and assessors. Generator create linguistic object and record the relationships of obedience in the input. Assessor in the hierarchy constraint is used to select the best candidates from the input as an optimal candidate produced by the generator. Constraint Sequence serves as an additional ranking of the major constraints in the series of constraint that illustrated in the Tawalmeni language as shown schematically below:

Input

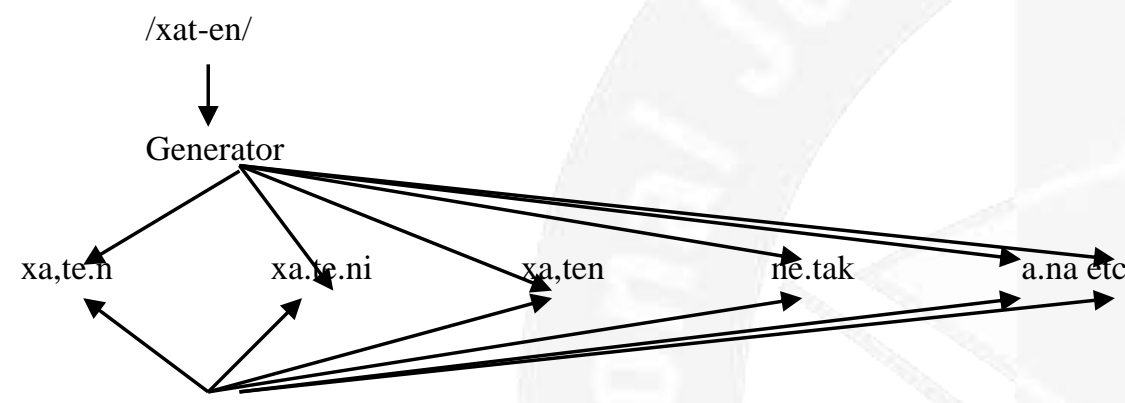

Input Optimal

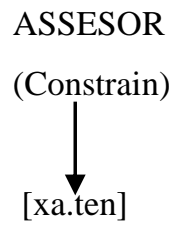

The scheme above is a formal model that describes:

[1] Generator for an input, then generator manages a set of constraint from the potential output.

[2] Assesor of the candidate series, generator change and select the best candidate which is the least degree of the offense as the optimal result form of output of the input.

Constrain assessor uses additional ratings of the major constraints in the series of universal constraints. From the scheme above, it could be explained that the role of instigator, assessor, and constrain systematically show how TO determine the optimal stem for / xat-en / entry. In instigator, the entry changed to candidates that possible in language. Candidates are considered by the assessor, to obtain the optimal candidate from the set of candidates that is offered.

Selection of the optimal candidate is determined by whether or not fatal violation of the constraints and the high or low levels of constraint that is violated. Optimal candidate is a candidate that does not violate any constrain or the lowest level of constrain. To get a clear picture, the following table is displaying [xat.en] as the optimal candidate.

\begin{tabular}{|l|l|l|l|l|l|l|}
\hline$/$ Xat-en/ & TOP & ONSET & *KOMPL & STRICT K & STRICT V & BK KODA \\
\hline Xa.ten & & & & & & $*$ \\
\hline Xa.te.n & $* !$ & & & & & \\
\hline Xa.te & & & & $* !$ & & \\
\hline Xa.te.ni & & & & & $* !$ & \\
\hline
\end{tabular}

Phonology of Muna Language (Theoretical Review of Optimality) 
Table above shows that in the yawelmeni language, the constraint of BK KODA is violated. BK KODA constraints is being overcome by more important constraint and the more relevant constraint is obedience. It must fulfill the following requirements. First, it requires the observance of consonants between input and output (STRICT K). Second, requires vocal obedience (STRICT V) so that the violation of this two constraint is fatal in this language.

Phonology overview of Muna language includes an inventory of segmental phonemes, phoneme distribution, vocal series, consonants series and syllables patterns.

[a] Inventory of Segmental Phonemes

Vowel Phonemes

Muna language has five vocal phonemes (Sidu, 1990: 47). The fifth kind of vowel phonemes can be seen in diagram 1 below.

Chart 1

Vowel Phonemes of Muna Language

\begin{tabular}{llll}
\hline & front & center & back \\
\hline high & $\mathrm{i}$ & & $\mathrm{u}$ \\
high tense & $\mathrm{e}$ & $\mathrm{o}$ & \\
moderate loose & $\varepsilon$ & $\mathrm{a}$ & $\mathrm{J}$ \\
low & & $\mathrm{a}$ &
\end{tabular}

Based on the seven segments phonetic above, there are five segment of vocal origin; ie /i, $\varepsilon, u, ~ \supset, a /$. The fifth vocal origin can occupy the position of the beginning, middle or end.

1. Input vocal /i/ $<\mathrm{i}\rangle$

Vocal /i/ includes the front vocal, high

i/e: isa 'older brother/ sister'

wita 'soft'

2. Vocal $/ \varepsilon /<\mathrm{e}>$ suli 'return'

$\begin{array}{ll}\text { esa } & \text { 'lift' } \\ \text { weta } & \text { 'break' } \\ \text { sule } & \text { 'substitute' }\end{array}$

Vocal $/ \varepsilon /$ includes the front vocal, loose, middle

e/i: see 1.1

Vocal $/ \varepsilon /$ has the allophone $[\varepsilon]$ and $[\mathrm{e}]$. Vocal / $/$ / known as $[\mathrm{e}]$ before or after the round vocals while the vocal $[\varepsilon]$ is elsewhere.

/ku ca/

[deu] 'needle'

$/ \mathrm{pa} \varepsilon /$

[kuea] 'name of hawk'

$/$ En $\varepsilon /$

[pa $\varepsilon]$

[en $\varepsilon] \quad$ 'collect'

3. Vocal $/ \mathrm{u} /<\mathrm{u}>$

Vocal /u/ includes back vocal, high, round

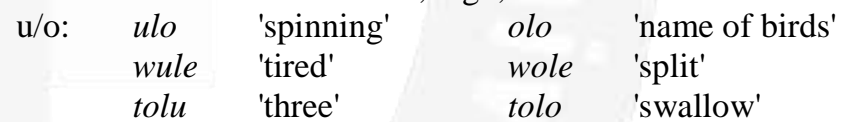

4. vocal $/ \mathrm{\jmath} /<_{0}>$

Vocal / $/$ / includes back vocal, loose, rounded

o / u: see 3.1

Vocal / $\mathrm{o} /$ has allophone [o] and [o]. Vocal / $\mathrm{o} /$ is known as [o] after or before rounded vocal, while [o] is at the other place.

Example:

lsoul [sou] 'mine'

lbus/ [buo] 'the young coconut fruit'

lombal [omba] 'appear'

5. Vocal $/ \mathrm{a} /\langle\mathrm{a}\rangle$

Vocal /a/ is included in back vocal, low, and hamper

a/o : alu 'eight' olu 'cloud'
wale 'cabin' wole 'slit'
towa 'kind of fish' towo 'smoke'

\section{Consonant Phoneme}

wale 'cabin' wole 'slit'

There are twenty-five consonant phonemes in Mn Language (Sidu, 1990: 34). The twenty five consonant phonemes can be seen at following diagram. 
Chart 2

Muna Language Consonant Phoneme

\begin{tabular}{|c|c|c|c|c|c|c|c|}
\hline & Labial & Labiodentals & Dental & alveolar & palatal & velar & glottal \\
\hline Closed explosive TB & $\mathrm{p}$ & & & $\mathrm{t}$ & & $\mathrm{k}$ & \\
\hline explosive B & $\mathrm{b}$ & & 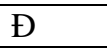 & $\mathrm{d}$ & & $\mathrm{g}$ & \\
\hline implosive & $\beta$ & & & & & & \\
\hline Friction TB & & & & $\mathrm{S}$ & & & $\mathrm{h}$ \\
\hline $\mathrm{B}$ & & $\mathrm{f}$ & & ${ }^{\mathrm{n}_{\mathrm{S}}}$ & & $\gamma$ & \\
\hline Nasal & $\mathrm{m}$ & & & $\mathrm{n}$ & & $\eta$ & \\
\hline Prenasal & ${ }^{m_{p}}$ & & & $\mathrm{n}_{\mathrm{t}}$ & & ${ }^{{ }} \mathrm{k}$ & \\
\hline & $\mathrm{m}_{\mathrm{b}}$ & & & ${ }^{\mathrm{n}} \mathrm{d}$ & & ${ }^{\mathrm{y}} \mathrm{g}$ & \\
\hline Trill & & & & $\mathrm{r}$ & & & \\
\hline Lateral & & & & 1 & & & \\
\hline Semi vocal & $\mathrm{W}$ & & & & & & \\
\hline
\end{tabular}

\section{Consonant phoneme distribution}

All consonant phonemes in Mn Language are only able at the beginning and middle position, in other words it can't be at the end position. Besides, Consonant phoneme in Mn language can't be placed at the end position of syllable too or as coda of syllable. It is because of Muna language is classified as vocalist language (Rene van Denberg, 1989:21, Sidu, 1990: 72). The twenty five of Mn language consonant phoneme can be known clearly at the following distribution.

6. Tap $/ \mathrm{p} /\langle\mathrm{p}\rangle$

Consonant $/ \mathrm{p} /$ is classified as closed consonant, unvoiced consonant, and bilabial. p/b/mb/ B / : : pea 'rotten', bea 'except', mbea 'appear', Bea 'areca nut' : topa 'fish', toba 'repent', tomba 'basket', toBa 'dig'.

7. Enter consonant $/ \mathrm{b} /\langle\mathrm{b}\rangle$

Consonant $/ \mathrm{b} /$ included blocked consonant, voiced, bilabial $\mathrm{b} / \mathrm{p} / \mathrm{mb} / 6 / \mathrm{see} 6.1$

8. Enter consonant $/ \mathrm{mp} /$

Consonant $/ \mathrm{mp} /$ included prenasal consonant, not voiced, bilabial

$\mathrm{mp} / \mathrm{p} / \mathrm{mb}$ б / mpali 'like going' pali ' fish's name' mbali ' make' sempa ' deviate' sepa 'kick' samba' hit' seбa 'notch'

9. Enter consonant $/ \mathrm{mb} /<\mathrm{mb}>$

Consonant $/ \mathrm{mb}$ / included prenasal consonant, voiced, bilabial

$\mathrm{mb} / \mathrm{mp} \quad$ : lihat 8.1

10. Enter consonant $/ \mathrm{B} /<\mathrm{bh}>$

Consonant / $\mathrm{\sigma} /$ included implosive consonant, voiced, bilabial

/ б/ $\mathrm{p} / \mathrm{mp} / \mathrm{mb}$ : see 8.1

11. Enter consonant $/ \mathrm{m} /\langle\mathrm{m}>$

$\mathrm{m} / \mathrm{mp}$ : manu 'chicken' mpanu 'stench of urine'

$$
\text { kama 'grip' kampa ' thick' }
$$

12. Enter consonant $/ \mathrm{w} /\langle\mathrm{w}\rangle$

Consonant $/ \mathrm{w} /$ included aproksiman consonant, voiced, bilabial

$\mathrm{w} / \mathrm{m} \quad$ : wanu 'wake up' manu 'chicken'

$$
\text { wawa 'underneath' mama 'chew' }
$$

13. Enter consonant $/ \mathrm{f} /\langle\mathrm{f}\rangle$

Consonant $/ \mathrm{f} /$ included fricative consonant, not voiced, labiodentals

$\begin{array}{ll}\mathrm{f} / \mathrm{p} \quad \text { : fula 'hurry' } & \text { pula 'fall down' } \\ \text { tofa ' beat' } & \text { topa 'dry fish' }\end{array}$

14. Enter consonant / ð / <dh>

Consonant / ð / included blocked consonant, voiced, dental

ə/t/d/ : ðangku 'beard' tangku 'near' dangku 'tight' kaðu 'woven' katu 'model' kadu 'sack'

15. Enter consonant $/ \mathrm{t} /\langle\mathrm{t}\rangle$

Consonant $/ \mathrm{t} /$ included blocked consonant, not voiced, dental/ alveolar

$\mathrm{t} / \mathrm{d} / \mathrm{d} / \quad$ : see 14.1 
16. Enter consonant /d/

Consonant /d/ included blocked consonant, dental/ alveolar, voiced

$\mathrm{d} / \mathrm{d} / \mathrm{t} \quad$ : see 14.1

17. Enter consonant / nt /

Consonant /nt/ included prenasal consonant, not voiced, dental/ alveolar $\mathrm{nt} / \mathrm{t} / \mathrm{n}$ : $\quad$ ntai 'suspend' tai ' stick nai 'pointed'

18. Enter consonant $/ \mathrm{nd} /\langle\mathrm{nd}>$ wanta 'long' wata'stem' wana 'poop'

Consonant /nd/ included prenasal consonant, voiced, alveolar

$$
\begin{array}{lll}
\mathrm{nd} / \mathrm{nt} & : \text { ndawu 'fall' } & \text { ntawu 'heaps' } \\
& \text { yondo 'see' } & \text { ronto ' close' }
\end{array}
$$

19. Enter consonant $/ \mathrm{n} /\langle\mathrm{n}\rangle$

Consonant $/ \mathrm{n} /$ included nasal consonant, voiced, alveolar

$\mathrm{n} / \mathrm{t} / \mathrm{nt} \quad$ : see 17.1

20. Enter consonant $/ \mathrm{s} /\langle\mathrm{s}\rangle$

Consonant / s / <s > including fricatives, voiceless, alveolar.

$$
\begin{array}{cc}
\text { s. ns } \quad \text { siri 'Incision' } & \text { nsiri 'shave' } \\
\text { Lesi 'male' } & \text { lensi 'open' }
\end{array}
$$

21. Enter consonant $/ \mathrm{ns} /<\mathrm{nd}>$

Consonant /ns/ including prenasal consonants, voiceless, silent alveolar,

ns/s : see 20.1

22. Enter consonant $/ \mathrm{r} /\langle\mathrm{r}\rangle$

Consonant $/ \mathrm{r} /\langle\mathrm{r}\rangle$ including shakes consonants, silent alveolar,

$\mathrm{r} / \mathrm{l} \quad$ : rako 'catch' lako 'cut' raro 'lapar' ralo 'hornbills'

23. Enter consonant $/ 1 /<1>$

Consonant $/ 1 /<1>$ including lateral consonant, voiced, alveolar,

$1 / \mathrm{r} \quad$ : see 22.1

24 Enter consonant $/ \mathrm{k} /\langle\mathrm{k}>$

Consonant $/ \mathrm{k} /$ including resistor consonants, voiceless, velar,

$\mathrm{k} / \mathrm{g} / \eta \mathrm{k} /$ : kuru 'shaving guru 'teacher' $\eta k u r u$ 'moody Taka 'part' taga 'climb' tanka 'impervious'

25. Enter consonant $/ \mathrm{g} /\langle\mathrm{g}>$

Consonant /g/ including resistor consonants, voiced, velar,

$\mathrm{g} / \mathrm{k} / \eta \mathrm{k} \quad$ : see 24.1

26. Enter Consonant $/ \mathrm{y} /<\mathrm{ng}>$

Consonant $/ \mathrm{y} /$ including prenasal consonant, voiceless, velar,

$\eta \mathrm{k} / \mathrm{k} / \mathrm{g} /$ : see 24.1

27 Enter consonant $/ \eta \mathrm{g} /<\mathrm{ngg}>$

Consonan $/ \mathrm{y} /$ including prenasal consonant, voiced, velar

$\eta \mathrm{g} / \mathrm{k}$ : yau 'moody/sad' gau 'cook'

$$
\text { Lena 'shaky' lega 'return' }
$$

28. Enter consonant $/ \mathrm{y} /<\mathrm{ng}>$

Consonant $/ \mathrm{y} /$ including nasal, voiced, velar

$\eta / \mathrm{g} \quad$ : yari 'lazy' gari 'drying',

29. Enter Consonant $/ \gamma /\langle\mathrm{gh}\rangle$

$$
\text { Loya 'visit' loga 'terrace' }
$$

Consonant $/ \gamma /$ including fricative consonant, voiced, velar,

$$
\gamma / \mathrm{hh} \quad \text { : } \gamma \text { oro 'throw away' horo 'fly' }
$$

$$
\text { Daro 'niggardly' daho 'stop' }
$$

30. Enter consonant $/ \mathrm{h} /$

Consonant $/ \mathrm{h} /$ including fricative consonant, voiceless, glottal

$\mathrm{h} / \gamma \quad$ : see 30.1

\section{Canonical Base of Morpheme Pattern}

Optimality theory looked syllable analyzed based constraints. Constraint is determined by the typical properties of syllables as contained in the common grammar. Therefore, for analyzing the syllables, first must be determined typical syllables properties. In general the typically syllable properties is 
1. TOP: syllable has a vowel

2. Onset: syllable begun single consonant

3.*COMPLEX: only one consonant at the edge syllable

4. NOCODA: syllable ends with a vowel

5. Onset \& PEAK: syllables formed of consonant and vocal

Patterns of Canon Morpheme Base

$\begin{array}{lll}\text { 1. V } & \text { a } & \text { 'waist' } \\ \text { 2. V.V } & \text { a.i' } & \text { brother' } \\ \text { 3. KV } & \beta \mathrm{e} & \text { 'and' } \\ \text { 4. KV.V } & \text { sa.i } & \text { 'snapped' } \\ \text { 5. V.KV } & \text { u.ta } & \text { 'stringed' } \\ \text { 6. KV.KV } & \text { bu.nta } & \text { 'middle' } \\ \text { 7. V.V.KV } & \text { a.i.ni } & \text { 'this' } \\ \text { 8. V.KV.V } & \text { u.lu.i } & \text { 'swivel' } \\ \text { 9. V.KV.KV } & \text { a.lo.ma } & \text { 'dew' } \\ \text { 10. KV.V.V } & \text { ta.e.o } & \text { 'sea urchin' } \\ \text { 11. KV.V.KV } & \text { sao.a.no } & \text { 'not' } \\ \text { 12. KV.KV.V } & \text { lo.yi.a } & \text { 'ginger' } \\ \text { 13. KV.KV.KV } & \text { yka.li.la } & \text { 'dizzy' } \\ \text { 14. KV.V.KV.V } & \text { ka.e.nu.a } & \text { 'bee' } \\ \text { 15. KV.V.KV.KV } & \text { ka.o.mbe.la } & \text { 'cottage' } \\ \text { 16. KV.V.V.KV } & \text { pa.e.a.sa } & \text { 'mirror' } \\ \text { 17. KV.KV.V.V } & \text { ka.pa.e.a } & \text { 'papaya' } \\ \text { 18. KV.KV.V.KV } & \text { ma.nsu.a.na } & \text { 'brides' } \\ \text { 19. KV.KV.KV.V } & \text { ma.ra.sa.i } & \text { 'miserable' } \\ \text { 20. KV.KV.KV.KV } & \text { la.wu.la. nya } & \text { 'ant name' } \\ \text { 21. KV.KV.KV.KV.KV } & \text { ka.pa.da.nta.na } & \text { 'deserts' } \\ \text { 22. KV.KV.KV.KV.V } & \text { la.le.mba.nu.a } & \text { 'Cockroaches' } \\ \text { 23. V.V.KV.V.KV } & \text { a.i.ni.i.ni } & \text { 'last' } \\ \text { 24. V.KV.KV.V.KV.V.KV } & \text { a.wa ya.i.ti.i.ni } & \text { 'yore' } \\ & & \end{array}$

Based on canonical pattern can be concluded that

[a] A word in Muna language can begin with a consonant or vocal.

[b] In the early edge word in Muna language not allowed more than one consonant.

[c] Muna Language allow their vocal series.Based on the principles obtained, constrain rating can be determined according the property general tendency of Muna language syllable.

\begin{tabular}{|l|l|l|}
\hline NO & \multicolumn{1}{|c|}{ Property } & General Tendency \\
\hline 1 & TOP: syllable has a vowel Always & Always \\
\hline 2 & Onset: single consonant syllable preceded & Always \\
\hline 3 & COMPLEX: only one consonant besides & Always \\
\hline 4 & NOCODA : syllable ends with a vowel & Always \\
\hline
\end{tabular}

The forth general property there is no violated in muna language, that are LOYAL K, ONSET, *KOMPLEKS, and, NOKODA... ONSET is not violated because there is word begins a vowel but never begin with a cluster consonant in muna language. Therefore, $\mathrm{VK}$ and $\mathrm{KV}$ pattern aceptable in muna language. *KOMPLEKS is not violated because in many words allows for no more than one consonant at the edge of the tribe. NOKODA is not violated because its not allowed at the end of syllabel in muna language. thus, pattern of KKV, KVK or KKVK are not received in muna langauge

Based on the general trends above by issue has determined the ranking of constraints. the sonority having important roles in determining the margin of the nucleus and syllables. simpai nucleus must be filled by segments louder than the segments on the simpai margin. Because of the vocals louder than consonants, vowels occupy the nucleus and consonant on ONSET and CODA. Therefore, TOP the highest rank in the konstrein. The Next rank is LOYALTY which is suggest loyality consonant between input and output (LOYAL K), and fidelity vocal (LOYAL V). The next are *KOM (prenasal), ONSET, *COMPLEKS, and NOCODA, the third are the lowest konstrain in the canonical pattern syllable muna language.

to see each konstrein violations can be proved by the analysis of words /lambu/ 'house' and /marasai/ 'misery' 


Optimal Candidate Lambu 'house'
\begin{tabular}{|l|l|l|l|l|}
\hline /'lambu/ & TOP & $\begin{array}{l}\text { *KOMP } \\
\text { (prenasal) }\end{array}$ & ONSET & NOKODA \\
\hline la.mbu & & & & \\
\hline lam-bu & & $* !$ & & \\
\hline la.m.bu & $* !$ & $* !$ & $*$ & $*$ \\
\hline lamb.u & & & $*$ & $* !$ \\
\hline l.amb.u & $* !$ & & $*$ & $* !$ \\
\hline
\end{tabular}

The most optimal candidate is the first candidate, la.mbu. the candidate did not violate constraints that exist, the second candidate violate of constraint LOYAL K and *KOMP (pre) thus fatal consequences. Honesly the second candidate violate too *COMP but not fatal. the third candidate there is violations fatal on the TOP and LOYAL K and *KOMP Pre constrain. The fourth candidate violate NOKODA so fatal. The fifth candidate violates TOP and NOKODA, but the offense is also fatal.

\section{Optimal Candidat: marasai 'misery'}

\begin{tabular}{|l|l|l|l|l|l|}
\hline$/$ marasai/ & TOP & LOYAL V & ONSET & $*$ KOMP & NOKODA \\
\hline /ma.ra.sa.i/ & & & $*$ & $*$ & \\
\hline /mar.a.sa.i/ & & & $*$ & $*$ & $* !$ \\
\hline /ma.ra.sa/ & & $* !$ & $*$ & $*$ & \\
\hline
\end{tabular}

The table above shows that the most optimal candidate is the first candidate, ma.ra.sa.i. This candidate has violated constraints of ONSET and *COMPLEX only, so it is not a fatal violation because the two constraints that are under constraint TOP, LOYAL V (TOP, LOYAL K, V >> ONSET LOYAL, * COMPLEX). The second candidate violates constraint of NOKODA which made fatal consequences. On the third candidate, the disappearances phoneme is occurred / i / so it makes fatal violations on LOYAL V.

Patterns of Canonical Affix of Muna Language

The table of Canonical Pattern Affix of Muna Language

\begin{tabular}{|c|c|c|c|c|}
\hline Canonical Pattern & Prefix & Suffix & Infix & Total \\
\hline VK & 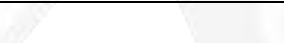 & & -um- & 1 \\
\hline $\mathrm{KV}$ & $\begin{array}{l}f e-, \text { fo-, } k a-, \quad k o-\text {, } \\
\text { po-, me-, sa-, mo-, } \\
\text { pa-, se-, ngko- }\end{array}$ & & & \\
\hline KVV & & -roo & & 1 \\
\hline KVKV & manso-, & & & \\
\hline
\end{tabular}

1. prefix fe-

2. Prefix fo-
/fe+lambu/ 'home'
felambu 'make home'

3. Prefix ka-

$$
\text { /fo+kala/ 'road' fokala 'ride' }
$$

Prefix ka- when is affixed to the base that starts with obstruent segments / p, f, t, s, k, g, y / sometimes it occurred prenasalitation process.

$/ \mathrm{ka}+$ pooli/ 'could'

/ka+ferawu/ 'grass'

/ka+tere/ 'afraid'

/ka+didiki/ 'small'

/ka+seba/ 'notch'

/ka+kona/ 'hit'

/ka+gaga/ 'deny'

/ka+ghuri/ 'life'

4. prefix ko-/

5. Prefix po-

6. Prefix me-

7. Prefix sa-

8. Prefix mo-

9. Prefix pa-

10) Prefix se-

11) Prefix yko-

12) Prefix manso-

/kampooli/ 'that is obtained'

/kampeYawu/ 'love grazing'

/katere/ 'coward'

/kadidiki/ 'small'

/kaseba/ 'notch'

/kangkona/ 'often get'

/kanggaga/ 'Like to deny'

/kangkuri/ 'love to life'

ko+kiri/ 'thorn'

/po+golu/ 'ball'

/me+ala/ 'take'

/sa+kala/ 'go'

/mo+lodo/ 'sleep'

/pa+hulu/ 'labor'

/se + yonu/ 'seed'

/ pko + amaral 'angry'

Imanso- + kalal 'go' /kokiri/ 'stand up'

/pogolu/ 'playing football'

/meala/ 'taking'

/sakala/ 'often go'

/molodo/ 'sleep'

/pahulu/ 'hunter'

/seyonu/ 'one seed'

/ykoamara/ 'easy angry'

Imansokala/ 'often go' 
Sufix

Sufix-yoo

Infix

infix -um- lala+-yoo/ 'take'

/-um- + kala/ 'go' /alayoo/ 'take it'

/kumala/ 'will go'

\section{Phonotactic system of Syllable of Muna Language}

In spoken language, words commonly consist of a row of sound that follow each other. The sound represents phoneme and allophone. Phoneme series follow a particular rule. A phoneme can follow another one that is determined according to the convention among the language users. Rule regulated the unit of phoneme in morpheme is phonotactic rule (Alwi, 2000: 28).

World of a language, optimality theory offers a problem solving with conflict resolution between two constraints, such as FAITHFULLNESS CONSTRAINTS and INDENTICAL CLUSTER CONSTRAINTS (ICC). FAITHFULLNESS CONSTRAINTS determined relationship identity between input and output. The faithfulness constraints will cause direct conflict with another constraint.

MAX-IO: Each segment or characteristics of input has identical correspondence with an output. DEP-IO: Each segment or characteristics of output has identical correspondence with an input. Problems of MAX-IO explain that each segment should has parable segment in output (without omitting phonology) and DEP-IO explains that each output segment should has parable segment in input (without epenthesis). This constraint is based on the simple constraint such as FAITH.

IDENTICAL CLUSTER CONSTRAINT has problems in syntagmatics that permits same articulator characteristics in a group of consonant, such as voicing, articulation place, occlusion, and nasal for a group of consonants.

Feature of IDENTICAL CLUSTER CONSTRAINT:

VOICING : A group of consonants should has same voicing.

PLACE $\quad:$ A group of consonants should has same articulation place.

CONTINUACY : A group of consonants should has same continuancy.

NASALITY : A group of consonants should has same nasality.

(Pulleyblank in Archangeli, 1997:64)

Function of ICC determined articulator devices to not shift - shift of articulator position is not allowed. In this case, the sequences should be the same type, both in the voicing, position of articulation, continuant, or opposition nasal. There is no composition of consonant in Muna language. On the contrary, there is only composition of vocal. Nasalization process occurs in Muna language that based on principle of homorganic. Model of nasalization that occurs in Muna language is a sequence of nasal consonants followed by oral consonant (obstruent). The characteristic of these consonants can be distinguished as follows: characteristic of nasal is nasal, stop, voiced, where $\mathrm{x}$ (position of $\mathrm{x}$ is soronant consonant variable above the articulation); whereas characteristic of obstruent is oral, stop or continuants, voiced or voiceless, where y (position of y is variable obtruents of values) (Pullyblank in Archangeli, 1997:65).

Based on data, there are three forms of nasal in Muna language, that is, $/ \mathrm{m} /, / \mathrm{n} /$, and $/ \mathrm{y} /$. These forms of nasal can be sequential with obstruents that have the same articulation with each nasal to form process of nasalization. In Muna language, the sequences of nasalization can be occurred not only in the beginning of the word, but also in the middle of the word. Data of process nasalization above appreas that prenasal segments are existed according to the position of articulation of consonants that followed. If the phoneme segment of base bilabial, so prenasal that will be exited is prenasal bilabial, such as [ $\mathbf{m p}, \mathbf{m p}$ ]; if the phoneme segment of base alveolar, so prenasal that will be exited is prenasal alveolar, such as [nt, nd]; and if phoneme segment of base velar, prenasal that will be exited is prenasal velar, such as $[\mathbf{n k}, \mathbf{n g}]$. It proves that the process of nasalization in Muna language is homorganic.

As stated above that there is no composition of consonants, so the writers do not conduct an analysis of phonotactic consonants. Also, there are prenasal phonemes in Muna language, such as /mb, mp, nd, nt, ns, ngk, ngg/. The examples of prenasal have stated above.

Further discussion focus on sequences of vocal.

1) Sequence of vocal /i/

Vocal /i/ can be sequenced with several vocals, such as vocal /i, e, a, o, u), for example:

Miina [mi? ina] 'no' tiene [tiene] 'limit'

Wiolo [wiolo] 'name of plant' falia [falia] 'forbidden of taboo' tiulu [tiulu] 'disappear'

2) Sequence of vocal /e/

Vocal /e/ can be sequenced with several vocals /i, e, u, o, a/, for example:

Feena [fe? ena] 'ask' bhei [bhei] 'spoiled'

Yoleo [yoleo] 'day' lea [lea] 'sick'

leu $[l e u]$ 'singe'

3) Sequence of vocal $/ \mathrm{u} /$ 
Vocal /u/ can be sequenced with several vocals, such as /i, e, u, o, a/, for example:

Luиno [lu? uno] 'teardrop' lui [lui] 'tough'

Lawue [lawue] 'legume' duo $[d u o]$ 'sheat of inflorescence of palm tree'

Kalua [kalua] 'bat'

4) Sequence of vocal /o/

Vowel O can be connected with vowels /i,e,u,o,a/ as an example tooka [ to?oka] 'so' koise [ koise] do not'

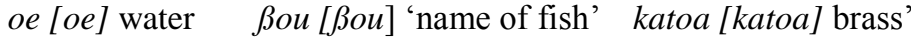

5) Diphthong /a/

Vowel /a/ can be connected with vowels /i,e,u,o,a/ as an example taaka [ta?aka] 'but' ßai [ßai] 'friend' pae [pae] rice plant' gau [gau] 'cook'

Based on the above data can be explained as follows:

If the vowel series is a series of the same sound so between them will occur glottalitation or addition glottal sound [?] like on the data

Miina [mi?ina] 'not' feena [fe? ena] ' ask' luuno [lu?uno] tears' tooka [to?oka] 'so' taa [ta?aka] 'but'

On the other words, phonetically between the series will occurs the strengthening of segment glottal sound become [?] so between that series the consonants appears directly becomes the next syllable onset. Based on the above data it can be said that the highest rank is STRICT (TP) than KKS (TP). Besides the both of constrain also used ONSET, ALIGN RIGHT, and DEP-IO (K). ALIGN RIGHT stating that the right end of the syllable should be equal to the right end or the word. In summary can be describe STRICT (TP) >>ONSET $>>$ ALIGN RIGHT $>$ KKS(TP) $>>$ DEP-IO(K).

Here is an analysis of optimality by using tables.

The word Taaka [ta?aka] 'but' as an input.

\begin{tabular}{|l|l|l|l|l|l|}
\hline /taaka/ & $\begin{array}{l}\text { STRICT } \\
(\mathrm{TP})\end{array}$ & ONSET & $\begin{array}{l}\text { ALIGN } \\
\text { RIGHT }\end{array}$ & KKS (TP) & $\begin{array}{l}\text { DEP-IO } \\
(\mathrm{K})\end{array}$ \\
\hline ta.a.ka & & $* !$ & & $*$ & \\
\hline ta.i.ka & $* !$ & $* !$ & & & \\
\hline ta.u.ka & $* !$ & $* !$ & $*$ & & \\
\hline ta.?a.ka & & & & & $*$ \\
\hline
\end{tabular}

The above data can be explained as follows:

The most optimal candidates on the above data Muna Language is ta? aka (fourth candidates) although breach happening on ALIGN RIGHT and DEP-IO (K). The breach of the both constrain is not fatal because the rank of this constrain is lower than STRICT and ONSET. The first candidate taaka unacceptable because it breaches of ONSET constrain. The breach to ONSET constitute fatal thing. Actually this candidate is acceptable phonemically, but phonetically it should be added glottal between the both of that series. The second and third candidate taika and tauka unacceptable because they breach of STRICT (TP) and ONSET constrain. The breach of this constrain is fatal even though there is not breach on KKS. In Muna language there are a row of vowel /a-u/ and /a-i/ but for this data is unacceptable.

Furthermore, based on the above data as well, if the vowel series is the different vowel series so there is not adding to the consonant phonetically. Besides that, it can be said if the vowel series on Muna language. Muna does not emphasize identical, but more likely to emphasize strict with another vocal in the form of words. Thus, it can be said that the ranking STRICT (place) higher than the KKS (place). Besides the two constraints DEP-IO (K) (no additional consonants) are also used in this analysis. Briefly, it can described STRICT (TP) $>$ DEP-IO $>$ KKS (TP)

This is an analysis of optimality by using tables.

Word tiulu [tiulu] 'missing' as input

\begin{tabular}{|l|l|l|l|}
\hline$/$ tilulu/ & STRICT (TP) & DEP - IO (K) & KKS (TP) \\
\hline [ti.u.lu] & & & $*$ \\
\hline [tuulu] & $* !$ & & \\
\hline [tikulu] & & $* !$ & $*$ \\
\hline
\end{tabular}

The data can be explained as follows.

The most optimal candidates on the data is Muna Language [tiulu] (the first candidate) despite an offense at KKS (TP). Violation of the KKS (TP) is not fatal things because these constraints ranks lower than STRICT. The second candidate, [tuulu] is unacceptable for this data because it violates STRICT constraints (TP). In the Muna language indeed there is a row vowel / $\mathrm{u}-\mathrm{u} /$ but for this data is not acceptable. Violation of this constraint is fatal even though there were no violations at KKS constraints. The third candidate [tikulu] is also not acceptable in the Muna language for violating constraint DEP-IO (K). Violation of these constraints is fatal. 


\section{Conclusion}

Based on the description above it can be concluded that the Muna language has seven segments phonetic on above, there are five segments vocal source; /i, $\varepsilon, \mathrm{u}, \mathrm{\rho}, \mathrm{a} /$. Fifth vocal source can be placed on beginning, middle, or the ending, and has twenty-five consonant phonemes that occupy only the beginning and the middle. Muna language has the general properties. Based on the principles that constrain ratings obtained may be determined according the general tendency syllable Muna language property.

\begin{tabular}{|l|l|l|}
\hline No & Property & General Tendency \\
\hline 1 & TOP: syllable has one vocal & Always \\
\hline 2 & ONSET: syllable was preceded the single consonant & Always \\
\hline 3 & $*$ COMPLEX: only one consonant at the edge of the syllable & Always \\
\hline 4 & NOCODA: syllable end with a vocal & Always \\
\hline
\end{tabular}

\section{Acknowledgement}

The success of writers in completing the writing is inseparable from the support of various parties. Therefore, through this paper the authors expressed thanks and high appreciation to Prof. Dr. Aron Meko Mbete, Prof. Dr. I Wayan Pastika, M.S., Prof. Dr. La Ode Sidu Marafad, M.S. because through this touch of the great teachers of this article can be resolved. Further to friends Hugo Warami, I Made Rajeg, Lien Darlina, thank you for the cooperation so far. Finally, the author would like to thank the author's family, especially his wife and children's author Herlina Pambau Rahma writer Wa La Ino who always provides encouragement to the authors, although they are left in the village writers. Unto them authors dedicate this paper.

\section{References}

[1] Archangeli, Diana \& D. Terence Langendoen. 1997. Optimality Theory An Overview. USA: Blackwell Publishers Ltd.

[2] Basri, Hasan. 2003. "An OT Account of Epenthetic Echo Vowels in Selayarese” dalam Kolita I. Jakarta: Pusat Kajian Bahasa dan Budaya Unika Atamajaya.

[3] Basri, Hasan. 2004. "Phonological Nativisation of Kailininese Loanword An Analysis in Optimality Theory" dalam Kolita 2. Jakarta: Pusat Kajian Bahasa dan Budaya Unika Atamajaya.

[4] Berg, Rene van den. 1989. A Grammar of the Muna Language. Leiden:KITLV Press.

[5] Dardowidjojo, Soenjono (penyunting). 1987. Linguistik: Teori dan Terapan. Jakarta : Arcan.

[6] Marafad, La Ode Sidu. 1990. Fonologi Generatif Bahasa Muna. Ujung Pandang:Unhas.

[7] Miles, Mathew B and Michael Huberman. 1992. Analisis Data Kualitatif. Jakarta: Universitas Indonesia,

[8] Prince, Alan \& Paul Smolensky. 2004. Optimality Theory Constrain Interaction in Generative Grammar. USA: Blackwell: Publishing Ltd.

[9] Refnaldi. 2005. "Nasal Subtitution in English, Indonesian, and Minangkabaunese: An Optimality Theory Analysisi” dalam MLI 2005. Sumatera Barat: Lembaga Penjamin Mutu Pendidikan

[10] Schane. 1992a. Fonologi Generatif. Jakarta: Summer Institute of Linguistiks.

[11] Subagia, I Ketut. 2007. "Fonlogi Bahasa Bugis di Kampung Bugis Desa Serangan: Kajian Berdasarkan Teori Optimalitas". Tesis Universitas Udayana.

[12] Sutama, I Gede Made. 2007. "Fonologi Bahasa Dayak Tamuan di Kalimatan Tengah: Analisis Berdasarkan Teori Optimalitas” Tesis Parogram Magister Lingusitik Universitas Udayana 


\section{Biography of Author}

\begin{tabular}{|l|l|}
\hline & \\
\hline & $\begin{array}{l}\text { Dr. La Ino, S.Pd., M.Hum. is full time lecturer of the Faculty of Humanities, Halu Oleo University, } \\
\text { Kendari Indonesia. He graduated his Master of Humanity in Udayana University Bali. Then, he } \\
\text { graduate his doctorate in Udayana University in Bali. La Ino born in Raha on September 26, 1971. } \\
\text { He wrote some articles in several differnt book and journals. Book: 1. Deskripsi Fonem Bahasa } \\
\text { di Sulawesi Tenggara Nomor ISBN: 978-602-1621-36-3, 2. Bahasa Indonesia dan KaryaTulis } \\
\text { Ilmiah Nomor ISBN: 978-602-71215-2-2, Journals: 1. Survival Vocabulary of Wuna Language } \\
\text { in Plant Environment of Kowala Publish International Research Journal of Management Sciences, } \\
\text { IT and Social (IRJMS) ISSN: 2395-7492 Volume 3, Issue 5, May 2016, 2. Makna Tuturan dalam } \\
\text { Penyelesaian Pelanggaran Adat Mambolosuako Masyarakat Tolaki Lingua Jurnal Ilmu Bahasa } \\
\text { dan Sastra ISSN 1693-4725, Vol. 6 No. 1, April 2010, 3. Proses Morfologis Prefiks dalam Bahasa } \\
\text { Wolio (Kajian Transformasi Generatif) Lingua Jurnal Ilmu Bahasa dan Sastra ISSN 1693-4725, } \\
\text { Vol. 6 No. 1, April 2011. Conference: 1. Kinship Relations in Kulisusu Language, Wawonii } \\
\text { Language, and Moronene Language (A Comparatif Analysis) Article Precenting in The 26 } \\
\text { Annual Meeting of the Southeast Asian Linguistic Siciety Manila Philippenes 26-28 May 2016, } \\
\text { 2. Derivational System of Ciacia language (a Study of Morphological). Proceeding Annual } \\
\text { International Conference ISSN 2251-3566 5 Conference on Language, Literature, and } \\
\text { Linguistics (L3 2016) 30-31 May 2016 in Singapura. }\end{array}$ \\
\hline & \multicolumn{1}{|c|}{} \\
\hline & \\
\hline
\end{tabular}

